\title{
THE ALTERNATIVE DESIGNS EFFORT TO SIMPLIFY THE NUMBER OF POLITICAL PARTIES IN INDONESIA
}

\author{
Sulistyani Eka Lestari \\ Sunan Bonang University \\ sulis usb@yahoo.com \\ Ahmad Siboy \\ Islamic University of Malang \\ siboysalman@unisma.ac.id
}

\begin{abstract}
The number of political parties continues to increase from time to time. Ironically, the establishment of a political party is not based on the desire to carry out the functions of political education, political recruitment, and political regeneration. It is only to fulfill the desire for the power of a group of political elites. This research aims to analyze the need to simplify the number of political parties and determine the ideal simplification design of political parties This research used normative juridical research with statutory, historical, and conceptual approaches. The results indicated that political party simplification is needed for creating effectiveness and efficiency, minimizing segmentation or the emergence of friction among Indonesian citizens, preventing voter confusion, and maintaining political stability. Meanwhile, the ideal design to simplify political parties that can be executed is through submitting the dissolution of political parties to the Constitutional Court (Indonesian: Mahkamah Konstitusi (MK)) by expanding the criteria for those who can propose for dissolution (legal standing), imposing strict sanctions, implementing a moratorium on permits for the establishment of new parties, and extending the authority of the government to unilaterally dissolve political parties, such as the power to dissolve banned community organizations.
\end{abstract}

Keywords: Administration Law; Electoral Policies; Constitutional Law; Political Parties.

\section{A. INTRODUCTION}

In principle, democracy has the meaning as a system of government that makes the people as the main pillar. That is, it is the people who hold the highest sovereignty over an organization called the State. Fareed Zakaria stated that the first and foremost meaning of democracy is government by the people. ${ }^{1}$

Democracy in Indonesia is a democratic popular sovereignty carried out by the constitution. ${ }^{2}$ The provisions of Article 1 paragraph (2) of the

1 Fareed Zakaria, Bangkitnya Demokrasi Yang Tak Liberal, Article Group Amerika Dan Dunia: Memperdebatkan Bentuk Baru Politik Internasional, Jakarta, Yayasan Obor Indonesia, page. 168

2 Article 1 Paragraph (1) Constitution of the Republic of Indonesia 1945. 
1945 Constitution of the Republic of Indonesia provide guidelines or limits that the democracy that applies in Indonesia is a democracy that is in accordance with the contents of the constitution so that the democracy adopted in Indonesia is often termed as constitutional democracy. According to Miriam Budiardjo, constitutional democracy is a government that has limited powers and it is not allowed to take arbitrary actions against its citizens and the limitations on government power are contained in the constitution. ${ }^{3}$

The constitution as a written form of the implementation of popular sovereignty has regulated the implementation of the sovereignty of the Indonesian people (democracy). That one form of popular sovereignty can be realized with equal rights for all Indonesian people to develop themselves in government. ${ }^{4}$ This means that every citizen has the same rights before the law and the government to be part of the government or ruler. Anyone and whatever the background of a citizen has the same opportunity to become a member of the House of Representatives (DPR), Regional Representatives Council (DPD) and even become President or Vice President. Equality of opportunity in terms of government is certainly in line with Abraham Lincoln's 1863 Speech in Gettysburg which briefly summarized from the people, by the people and for the people. ${ }^{5}$

Of course, to obtain these rights requires a process that must be passed. One of the processes as well as the concrete realization of this sovereignty is by participating in general elections (Pemilu). General elections are an official means provided by the constitution to accommodate the rights of the people to develop themselves in government. It is through this general election that all people can exercise their constitutional sovereignty in the form of the right to be elected and to vote. The general election itself is the implementation of people's sovereignty to elect members of the People's Representative Council (DPR), Regional Representative Council (DPD), Regional People's Representative Council (DPRD) and the President/Vice President. ${ }^{6}$

However, to be able to participate in the general election, every citizen must go through a political party (Parpol). Political parties are a means or vehicle for the people to be able to participate in general election contestations. Citizens can become members or cadres of already formed political parties or establish new parties.

In Indonesia, the number of political parties participating in the general election has experienced ups and downs in each election period. In the first general election, namely the 1955 election, there were 172 political parties, in the 1971 election there were 10 political parties, while in the new era general election, namely the 1977-1997 election, only two political

3 Miriam Budiardjo, 2008, Dasar-dasar Ilmu Politik, Revision Edition, Jakarta, PT Gramedia Pustaka Utama, page. 107.

4 Article 28 Paragraph (3) Constitution of the Republic of Indonesia 1945

5 Jane Theresia Silaban, dkk, Persepsi Mahasiswa Fisip Undip Terhadap Demokratisasi Di Indonesia, Jurnal IImu Pemerintahan, 2013, page. 5

6 Article 22 E Constitution of the Republic of Indonesia 1945 
parties and one work organization (Golkar) participated. ${ }^{7}$ The small number of political parties in the elections in the New Order regime could not be separated from the system of political party fusion imposed by President Suharto. After the fall of the New Order regime on May 21, 1998, in the next general election or in the 1999 election there were 48 political parties, in the 2004 election there were 24 political parties, in the 2009 election there were 38 political parties, in the 2014 election there were 12 political parties and In the 2014 election, there were 14 political parties. ${ }^{8}$

Table 1

The Political Parties Number in Each Election

\begin{tabular}{|l|l|l|}
\hline No & Election Year & $\begin{array}{l}\text { Number Of Political } \\
\text { Parties }\end{array}$ \\
\hline 1 & 1955 Election & 172 \\
\hline 2 & 1971 Election & 10 \\
\hline 3 & $1977-1997$ Election & 3 \\
\hline 10 & 1999 Election & 48 \\
\hline 11 & 2004 Election & 24 \\
\hline 12 & 2009 Election & 38 \\
\hline 13 & 2014 Election & 12 \\
\hline 14 & 2019 Election & 14 \\
\hline
\end{tabular}

The number of political parties in each general election certainly shows that the people can really feel the guarantee of association and assembly in the State of Indonesia. At the same time, the Indonesian people are people who want to actively participate in the democratic party (Election). With so many political parties being born, automatically every citizen has been represented in their political direction and voters also get many alternative choices. ${ }^{9}$

However, many political parties were not established on the basis of being a channel for political aspirations or for the benefit of the people. Political parties are founded on the basis of hurt or fulfilling the pragmatic interests of certain figures. Several political parties were founded because of internal conflicts within the political parties or the defeat of certain figures in the struggle for the chair of general chairman. For example, the National Democratic Party (NasDem) which was founded in 2011 was founded because its founder (Surya Paloh) lost the election for the general chairman of the Golkar Party. ${ }^{10}$ Recently there was the People's Wave Party (Gelora) which was founded by former President of the Prosperous Justice Party

7 Evi Noviati, Perkembangan Politik Hukum Pemilihan Umum Di Indonesia, Jurnal Galuh Yustisi, Volume 07 No. 1, March 2019, P. 79-84

8 https://nasional.kompas.com/read/2018/02/20/13275281/partai-politik-yang-bertarung-dipemilu-dari-masa-ke-masa?page=all

9 Diastama Anggita Ramadhan, Menuju Penyederhanaan Partai Politik di Indonesia serta Dampaknya Terhadap Persatuan Bangsa, Adminitrative Law \& Governance Journal, Volume 2 Issue 4, November 2019, page. 572

10 https://id.wikipedia.org/wiki/Partai_NasDem 
(PKS) Anis Matta. Anis Matta founded the Gelora party after he was no longer elected as PKS President.

As a result, many political parties were born not based on the need for the progress of the nation but only to fulfill the wishes of a few figures who needed a vehicle to gain power. Competition in the general election is not colored by the struggle for the vision and mission of the political parties or the ideas of each political party. Elections are colored more by money competition. Money politics is something that always accompanies the implementation of elections in Indonesia. ${ }^{11}$ This happens because each political party participating in the general election prioritizes victory or power so that the vision, mission and ideas of each political party are set aside while pragmatic methods such as money politics are encouraged. It is not surprising that the political parties that get significant votes are the political parties that have a significant supply of capital. This of course makes the general election a liberal and undemocratic election. From the above background, this study aims to analyze the need to simplify the number of political parties and determine the ideal simplification design of political parties.

\section{B. RESEARCH METHODS}

This research uses normative legal research with a statutory approach, concept approach, historical approach and case approach. ${ }^{12}$ Legal source materials include primary, secondary and tertiary legal sources. All legal materials are then collected through inventory and clarification.

\section{RESULTS AND DISCUSSION}

\section{Urgency and Efforts to Simplify the Number of Political Parties}

The rights of association and assembly are part of human rights (human rights) guaranteed by the Constitution. ${ }^{13}$ One form of embodiment of freedom of association and assembly is the right to establish political parties. Political parties are political organizations which can be established by anyone who can fulfill the requirements set out in the Political Party Law.

However, the freedom of association granted by the constitution is actually used by a group of political elites to establish political parties as a manifestation of achieving their political ambitions. This is evident from the number of political parties founded by one or a group of political elites who lost the congress for the election of their party's chairman and then established a new party. As a result of such a mindset and attitude pattern, the number of political parties continues to increase from time

11 Aras Firdaus, Money Politic Dalam Pemilihan Umum Oleh Badan Pengawasan Pemilihan Umum: Pengawasan Tindak Pidana Pemilu, Jurnal Justiqa, Vol.02 No. 01, February 2020, page. 61

12 Depri Liber Sonata, Metode Penelitian Hukum Normatif dan Empiris: Kharakteristik Khas dari Metode Meneliti Hukum, Jurnal IImu Hukum Fiat Justicia, Volume 8 No. 1, January-March 2014, page. 25

13 Pasal 28 Constitution of the Republic of Indonesia 1945. 
to time, causing unclear differences in the vision, mission and ideology of each political party.

The large number of political parties that stand and participate in the general election is certainly something that can cause obesity in the multi-party system that applies in Indonesia. Obesity in the number of political parties is certainly not good for the dynamics of democracy in Indonesia, so it is necessary to reduce or simplify political parties. Simplification of political parties is needed because: First, the argument for simplification of political parties in Indonesia is for the sake of effectiveness and efficiency in the implementation of elections. Because, with fewer and fewer political parties participating in the general election, the effectiveness and efficiency of the general election will increase. $^{14}$

Effectiveness is created because with a small number of political parties, the time used for administrative verification of political parties will be minimal. At the same time, the process of voting and counting votes will be much faster and more precise. Efficiency is created when the number of political parties participating in the general election is small, which is related to the funds spent. The budget that will be spent in elections with a small number of political parties will be much lower with the budget used for elections with a large number of political parties. In this case, the budget for printing ballot papers can be taken as an example. Ballot paper with a small number of political parties is certainly cheaper than ballot paper with a large number of political parties. The fewer political parties participating in the general election, the smaller the number of ballot papers that must be printed. Smaller ballot papers certainly have a cheaper price than larger paper.

Second, the simplification of political parties also minimizes segmentation or the emergence of friction among Indonesian citizens, considering that fewer and fewer political parties are participating in the general election, it will reduce mass grouping based on ethnicity, religion, race, inter-group (SARA) or geographic which has the potential to trigger horizontal conflict.

Third, prevent voter confusion. The small number of political parties in the general election can also reduce confusion among voters. This is because the large number of political parties participating in the election often confuses voters to distinguish one political party from another. At the same time, voters do not have sufficient time to understand the identity of each political party participating in the general election so that often voters make their choices not based on rational considerations or based on considerations of compatibility with the vision and mission of a political party with themselves.

Fourth, political stability. The fewer political parties participating in the general election, it will automatically reduce political noise so that

14 Aprista Ristyawati, Fifiana Wisnaeni, Hasyim Asy'ari, Penyederhanaan Partai Politik Dalam Sistem Kepartaian Di Indonesia Sejak Perubahan Undang-Undang 1945, Diponegoro Law Review, Volume 5 No. 2, March 2016, page. 10 
political stability during the general election will be more conducive. ${ }^{15}$ The small number of political parties will certainly result in ease in the division of parliamentary seats. The small number of political parties will automatically reduce the number of factions in the DPR so that political communication between factions will be much simpler and more controlled. The composition of political power in parliament will be easily mapped from the start so that it can prevent political acrobatics carried out by small party factions which often cause chaos and deadlock in the policy-making process.

On the other hand, simplification of political parties or efforts to reduce the number of political parties participating in the general election is interpreted as an effort to limit the space for movement or freedom of citizens to assemble and associate. The simplification of political parties is considered to be able to make citizens not have the freedom to form new parties that are in accordance with their ideology or vision. Citizens feel that they must join a political party that has already been formed, even though the political party tends to be inconsistent with the wishes of their conscience. As a result, a citizen joins a political party not because of love and ideological similarities but because of the forced conditions in order to participate in the election.

Elections that are held with few political party participants will facilitate vote buying during the election. With a small number of political parties, voter mapping can be calculated easily and at the same time, the mapping of the estimated vote base of each political party can be tracked so that certain political parties can find out in which areas they have to spend funds to buy voters' votes.

In such conditions, political parties that have sufficient financial strength will win the political battle. Political parties with lots of wealth can pour quite a lot of funds in directing voters. As a result, it is certain that the rich party will come out victorious, especially since the party is currently a rolling party where the back-up power is in its ranks. This kind of thing is proven by the success of the ruling party (Golkar) which won five times in a row in the 7 elections that were followed. In the 1977 elections Golkar won 62.11\%. PPP: 29.29\%. PDI.8.60\%. In the 1982 election, Golkar won 64.34\%. PPP: 27.78\%. PDI.7.88\%. In the 1987 election Golkar won 73.16\%. PPP:15,97\%. PDI.10.87.\%. In the 1992 election, Golkar won 68.10\%. PPP:17,10 \%. PDI.14.89\%. Meanwhile, in the last election of the New Order regime, in 1997, Golkar won $74.51 \%$. PPP. $22.43 \%$. PDI.3.06 \%. ${ }^{16}$

Admittedly or not, the number of political parties in Indonesia has proven to be ineffective in consolidating democracy in Indonesia. Therefore, various efforts are needed to reduce or simplify the number

15 Alya Yuliamaryam, Firdha Azkia, Prima Bhakti Persada, Wilda Nurfitriani, Hana Novia Wijaya, Abiyyu Ihsan Samudro, Penyederhanaan Partai Politik Berdasarkan Undang-Undang Pemilu 2017, Padjajaran Law Review, Volume 6 December 2018, page. 96

16 Efriza and Syafuan Rozi, Parlemen Indoensia: geliat volksroad hingga DPD, Bandung, ALFABETA. page. 50 
of political parties. Various efforts to simplify political parties continue to be made from time to time. Some of the steps taken are: first, the fusion of political parties. The fusion of political parties is a structured mechanism carried out by the new order government (1977-1998) to limit the number of political parties participating in the general election. The government at that time only legalized two political parties and one work organization that could participate in the general election so that ten political parties that had participated in the 1971 elections (NU, Permusi, PNI, PSII, Parkindo, Catholic, Perti, IPKI and Murba) had to merge (fusion) into three types of groups. Namely, the Nationalist / Material Spiritualist group, the Spiritual / Spiritual Material group and the work group or the work group. This fusion was legitimized through Act No. 3 Year 1975 concerning Political Parties and the Working Group. From this provision, there were only two political parties and one work organization or Golkar. PNI, PKI, Catholic Party, Parkindo and Murba became the Democratic Party of Struggle (PDI). Parmusi, NU, PSII and Perti formed the United Development Party (PPP). The two parties that were born were added to a work organization, namely Golkar. ${ }^{17}$

Secondly, parliamentary threshold. ${ }^{18}$ Parliamentary threshold (PT) is the minimum number or threshold of vote acquisition that must be achieved by a political party to be able to place its cadres as members of the People's Representative Council (DPR RI). The threshold number from election to election continues to be raised so that the number of political parties that manage to have seats in the DPR continues to decrease.

Third, the weighting of the requirements. One way to reduce the number of political parties, both in terms of establishment and as election participants, is through increasing the standard requirements for the establishment of political parties. The more requirements that must be met to establish a political party, it will automatically result in at least one political party that can be legalized as a political party because many political parties do not meet the requirements as political parties as regulated in the legislation. ${ }^{19}$

\section{The Political Party Simplification of Alternative Design}

The various efforts to simplify political parties carried out above are considered ineffective in stemming or reducing the number of political parties in Indonesia, so several new design models are needed in addition. Among the additional designs may include: First, constitutional dissolution. The provision of a mechanism for dissolving political parties through a process at the Constitutional Court is one of the spaces provided to reduce the number of political parties. With the

17 Ahmad Siboy, 2013, Membongkar Politisasi Fungsi DPR, Malang, Intimedia, page. 14

18 Sutradara Gintings dan Ryaas Rasyid dalam Sunny Ummul Firdaus, Relevansi Parliamentary

Thresholdterhadap PelaksanaanPemilu yang Demokratis, Jurnal Konstitusi, Volume 8, Nomor 2, April 2010, page. 93

19 Act No. 2 of 2011 on Political Parties 
dissolution mechanism by the Constitutional Court, the number of political parties can automatically be reduced by applying for dissolution to the Constitutional Court.

The reduction of political parties through an application to the Constitutional Court is certainly an alternative to reducing the number of constitutional political parties. Because, when the Constitutional Court decides to dissolve a political party, the decision is an incraht legal decision. Legal decisions are decisions that must be respected by anyone considering that in a state of law, judicial decisions are decisions that determine whether something is right or wrong, fair or unfair, right or wrong, including the presence of political parties whether the existence of a political party is detrimental to Indonesian democracy or not. . The Constitutional Court's decision regarding the dissolution of political parties is certainly in accordance with the function of the Constitutional Court as a guardian of democracy. ${ }^{20}$

At the same time, when a political party is dissolved by the Constitutional Court, the argument that the dissolution of a political party is contrary to the principles or freedom of association or assembly cannot be put forward. This is because the Constitutional Court is an institution that also has the authority to limit human rights, including the right to establish political parties.

However, reducing the number of political parties through the dissolution of the Constitutional Court is a very difficult and political effort to take. It is difficult because the only one who can be an applicant in terms of dissolving a political party is the President/government. ${ }^{21}$ This is of course very difficult. Because, it is almost certain that a President will not apply for the dissolution of a political party to the Constitutional Court. This is because:

a. For the president, submitting an application for the dissolution of a political party to the Constitutional Court is a step that carries a considerable political risk;

b. The President is a person who can become a presidential candidate because it is proposed by a political party so that if the President proposes to disband a political party to the Constitutional Court, it is automatically the same as declaring that the party that carries him to become President is a party that has problems or is unfit to be a living party in Indonesia because jeopardize democracy;

c. The president is often the general chairman of a political party or a cadre of a political party, so it is impossible for him to propose the dissolution of the political party he leads. Proposing the dissolution of a political party against a political party he leads himself or a political party in which he is a high-ranking official is certainly an act of "suicide.".

20 Achmad Edi Subiyanto, 2019, Hakim Konstitusi: Kekuasaan Kehakiman dan Pengisian Jabatan, Depok, Rajawali Press, page. 61

21 Article 68 UU MK 7 of 2020 concerning the third amendment to Act No. 24 of 2003 concerning the Constitutional Court. 
d. If the President submits a request for the dissolution of a political party, the President can get feedback from the Political Party that is being requested to be dissolved. The feedback from political parties can be seen from the various efforts made by their cadres in the DPR which will continue to hamper the government's work and will even garner support for impeaching the President. From here then what will make the President will not dare to propose the dissolution of political parties to the Constitutional Court so that efforts to reduce political parties through the pro justicia mechanism in the Constitutional Court are very difficult to achieve.

Therefore, in the design of the constitutional reduction of political parties through the Constitutional Court, it is necessary to expand the authority of the parties who can propose the dissolution of political parties to the Constitutional Court. Several parties who may be granted the right to propose the dissolution of a Political Party to the Constitutional Court are:

a. Political party cadres should be parties with legal standing to be able to apply for the dissolution of political parties. Political parties are people or parties who know the ins and outs, goals and performance of their political parties, both performance which includes endangering democratic life.

b. Founding father. The founder of a political party is an absolute person or party to be given legal standing as an applicant in an application for the dissolution of a political party. As the founder of a political party, the person concerned can know about the history and basis of the founding of the political party as well as its current conditions. Because, it is possible for a political party to actually be established to take part in the development of democracy in a country but after a long period of existence, the political party loses its original purpose and even contradicts the original purpose of its establishment. This can be seen from the many founders of political parties who feel that the political parties they establish are no longer in accordance with the vision and mission at the time of their formation/establishment.

c. Public. Indeed, the public must also be given the opportunity to become an applicant for the dissolution of a political party to the Constitutional Court. Because, a political party is a public organization or a public legal entity because the existence of a political party is intended for all citizens so that if there are citizens who feel aggrieved by the presence of a political party, they must automatically be given the opportunity to apply for the dissolution of a political party because many citizens feel that harmed by the presence of a political party but cannot do anything. Providing an opportunity for citizens to be able to apply for the dissolution of a political party to the Constitutional Court can be analogous to the opportunity for every citizen to be able to submit a judicial review or 
annulment of a law to the Constitutional Court. ${ }^{22}$ Whereas the law is a legal product of the President and the DPR. That is, everything related to citizens automatically requires every citizen to be given the right to file a lawsuit if they feel aggrieved.

Second, sanctions. According to Berge, sanctions are "tanden van het recht" or the fangs of the law. ${ }^{23}$ One of the appropriate designs to simplify political parties in Indonesia is to impose sanctions on political parties. Giving sanctions to political parties is an alternative that can be taken because by imposing sanctions on political parties, the political parties that receive sanctions will automatically disband, thereby reducing the number of existing political parties.

However, the mechanism for imposing sanctions on political parties is a very difficult thing to implement. Because, to be able to impose sanctions on a political party, it must first be proven that a political party to be sanctioned has been proven to have committed a violation considering that there is no sanction without a violation. To declare that a political party has committed a violation or criminal act is not an easy matter. This is because political parties are an organization. Proving a crime or violation of an organization is not easy. An institutional political party can be said to have committed a criminal act such as corruption if the act of corruption was officially decided by the party. Proving an offense like this is certainly an impossible thing. Because, it is impossible for a political party to issue an official decision to commit a criminal act of corruption considering that from the beginning the act of corruption has been understood as an act that violates the law which if it is proven to be caught it will be fatal to the existence of a political party so that acts of corruption committed by political parties are carried out quietly but systematically. Such a mode of corruption will certainly make it difficult for law enforcement to ensnare it. Even if it is proven that there are political party officials who are corrupt, the corruption act is qualified as an individual corruption act, not a political party institution, even though it is the general chairman of the political party who commits corruption and the proceeds of corruption are used for political party activities.

Therefore, there must be a more theoretical and normative approach in the application of sanctions against political parties. The approach that can be taken is the structure and function approach. The structural approach is put forward because with this structural theory approach, political parties can no longer deny or deny the acts of corruption committed by their administrators. The approach to this structure theory, for example, is that when there is a general chairman of a political party who uses his position in the management of a political party to commit corruption, the corruption committed by the

22 Article No. 51 UU MK

23 J.B.J.M. ten Berge, Bescherming Tegen Overheid, (Zwolle: W.E.J. Tjenk Wilink, 1995), page. 93 Dalam Ridwan, 2009, Tiga Dimensi Hukum Administrasi dan Peradilan Administrasi, Yogyakarta, FH UII Press, page. 110. 
administrator of the political party can be said to be corruption of a political party For example, there is a general chairman of a political party who corrupts projects at the Ministry of Agriculture. The general chairman can commit acts of corruption in the Ministry of Agriculture because the cadres of the political parties are the cadres of the agriculture ministers. This means that acts of corruption in the Ministry of Agriculture occur because of the cooperation between the general chairman of a political party and his cadres who become the Minister of Agriculture in order to benefit from the use of the APBN or the authority possessed by a minister. This form of corruption committed by a general chairman of a political party can be qualified as a political party crime because in this model crime (at the Ministry of Agriculture) there is a pattern of cooperation based on the organizational structure of a political party.

On the other hand, even though a political party is sanctioned because it is proven to have committed a criminal act of corruption, this does not automatically mean the dissolution of a political party. A political party that is convicted by the court of being proven to have committed a corruption violation cannot be dissolved by itself because the court's decision to adjudicate corruption (in this case the Corruption Court) only decides related to the criminal act of corruption, not the existence of a political party. The dissolution of a political party can only be carried out through a judicial process at the Constitutional Court considering that the authority to dissolve a political party is the absolute competence of the Constitutional Court (Article 24C of the 1945 Constitution of the Republic of Indonesia) and not other judicial institutions.

Third. The moratorium on requests for and ratification of the establishment of political parties is also a wise step to reduce or simplify the number of political parties in Indonesia. This means that the government may issue a decision to temporarily stop the process of granting permits and legal entity status to new political parties. With this moratorium, the presence of new political parties can be prevented. The moratorium is an absolute authority inherent in the institution of the Ministry of Law and Human Rights (Kemenhukam).

The moratorium also cannot be interpreted as extreme that the government is not pleased with the establishment of political parties. The moratorium is a legal policy needed by the government to evaluate the dynamics of the development of existing political parties. This kind of moratorium has been carried out by the Ministry of Administrative Reform and Bureaucratic Reform (KEMENPAN-RB) in terms of the recruitment of new State Civil Apparatuses (ASN). ${ }^{24}$ Where for five years, KEMENPAN-RB did not open vacancies or accept new ASN on the grounds of evaluating and structuring the number of existing ASN.

24 Mustaqiem, Moratorium Penerimaan Calon Pengawai Negeri Sipil dan Aspek Hukumnya, Jurnal Kebijakan dan Manajemen, PNS VOL. 5, No.2, November 2011, page. 36. 
Fourth, the people do not vote. The fourth way is the reduction of political parties which is by nature. This means that political parties will disband because they do not get the trust of the people. Only a few people choose a political party in the general election (Pemilu) so that a political party that does not get a significant vote in the election will automatically dissolve itself considering that it is no longer possible for a political party to survive if it is not desired by the people. Moreover, the operational costs of political parties are very expensive so that it will be detrimental to the management.

However, this mechanism for reducing political parties by nature is very difficult to implement in Indonesia. Because Indonesian voters are still classified as irrational voters. That is, Indonesian voters choose a political party not based on the vision and mission of a political party but because of the emotional closeness factor with the cadres who are the administrators of a political party. This is evident from the shift in the choice of political parties chosen by Indonesian voters. Indonesian voters are inconsistent with the political parties chosen in each election. In fact, if Indonesian voters choose a political party based on rational considerations such as ideological considerations, the choice of Indonesian voters towards a political party will remain consistent from election to election.

From the condition of the Indonesian voters, it is then that becomes the basis for the emergence of new parties in the run-up to the election. New parties participating in the election for the first time were able to beat old parties in terms of votes, such as the National Democratic Party (NasDem Party) in the 2014 election. The 2014 election was the first general election followed by the National Democratic Party and won the Nasdem Party's votes. 8,402,812 (6.72 percent). The NasDem Party's vote gains far surpassed those of parties that have participated in elections several times, such as the Crescent Star Party (PBB) and the Indonesian Justice and Unity Party, the Hanura Party and the United Development Party. ${ }^{25}$

Fifth, Identity of Political Parties. Political parties, whether existing or to be formed, must have a clear identity difference with other parties. This clarity on the identity of each political party will automatically reduce the number of political parties. If the identity of one political party does not differ from one another, then there should be no need for a different political party or establishing a new political party, but only one political party or joining a political party that has already been formed.

This identity is important in order to reduce the number of political parties that already exist but do not have a clear difference between one party and another so that there are often more than one political party that has the same identity so that the mass base being contested is the same so that it often causes conflict between others. Political party. In this case, an example can be taken of several Islamic parties such as the

25https://nasional.kompas.com/read/2014/05/09/2357075/Disahkan.KPU.Ini.Perolehan.Suara.P emilu.Legislatif. 2014 
National Awakening Party (PKB) and the United Development Party (PPP). These two Islamic parties (PKB and PPP) almost have the same identity. Namely, all Islamic parties that seek to represent the Ahlusunnah wal Jama'ah Islamic party on the basis of the votes being contested are the nahdiyin (members of Nadhlatul Ulama).

New parties with identities that are not different from the previous parties are also trying to be established and included in the general election. Recently, the former President of the Prosperous Justice Party (PKS) founded the People's Wave Party (Partai Gelora). Meanwhile, the former founder and general chairman of the National Mandate Party (PAN) founded the Reform-National Mandate Party. Amien Rais founded the PAN-reformasi party with the same identity and mass base as the National Mandate Party. When the identity of a political party is not used as the basis for limiting the number of political parties, efforts to reduce the number of political parties will never materialize considering the spirit of the establishment of political parties that prevails in Indonesia on the basis of dissatisfaction with existing parties, even though the establishment of political parties without differences in identity can trigger potential conflicts between brothers in a mass base at the grassroots level. For example, between PPP and PKB supporters who are both Nahdhlatul Ulama member.

Sixth, disbandment by the government. The government can also disband political parties, especially the Ministry of Law and Human Rights. The government can be given the authority to dissolve a political party because the government is the institution that grants permits and legitimizes the establishment of political parties. That is, as an institution that ratifies the establishment of a political party, the government can automatically dissolve a political party. The authority to dissolve political parties by the government is a contratius actus which is allowed in state administrative law. ${ }^{26}$

The dissolution of a political party by the government is certainly a dissolution of which the risk is quite large politically considering that the dissolution of a political party by the government will always be seen as an attempt by the authorities to destroy their political opponents. This assumption is certainly not entirely true because the Ministry of Law and Human Rights (Kemenhukam) is led by cadres of political parties such as the Minister of Law and Human Rights for the period 2009-2014 who are cadres of the ruling party or the Democratic Party. Period 2014-2019 and 2019-2024 who are cadres of the Indonesian Democratic Party of Struggle (PDI-P).

However, this does not mean that political reasons can prevent the government from being given the authority to dissolve political parties. The dissolution of a political party by the government is a legal act of a state administrative official or not a political act. The government

26 Imam Sukadi, Asas Contrarius Actus Sebagai Kontrol Pemerintah Terhadap Kebebasan Berserikat dan Berkumpul Di Indonesia, Jurnal Mimbar Keadilan, Volume 12 Nomor 2 August 2019 -January 2020, page. 183 
as a state administrator can disband a political party if it considers a political party to be interfering with the public interest. Meanwhile, for parties who feel that the government's legal action to dissolve a political party is considered an act that is not in accordance with the legal corridor, they can file a lawsuit to the court, especially the State Administrative Court. That is, if the arguments of the Minister of Law and Human Rights are not legally grounded, the dissolution of a political party by the Ministry of Law and Security can be annulled through a court decision.

The granting of authority to dissolve political parties to the government (Kemenhukam) can be analogous to the government's authority in terms of disbanding community organizations such as the dissolution of Hizbut Tahrir Indonesia community organizations (mass organizations) On July 19, 2017 where the Ministry of Law and Human Rights officially revoked the legal entity status of Hizbut Tahrir Indonesia's mass organizations. (HTI) based on the Decree of the Minister of Law and Human Rights Number AHU-30.AH.01.08 of 2017 concerning the revocation of the Decree of the Minister of Law and Human Rights Number AHU-0028.60.10.2014 concerning the ratification of the establishment of a legal entity association of $\mathrm{HTI} .^{27}$

\section{CONCLUSION}

Political parties are a form of embodiment of association guaranteed by the constitution as part of human rights (HAM). The establishment of political parties is expected to be a forum for citizens' political aspirations to develop themselves in government. In practice, the establishment of political parties is not based on an intrinsic intention to strengthen democracy, but political parties are founded only because of the political desire of a group of elites who do not have space or lose in the struggle for power within their previous internal parties, so they choose to leave and establish a new party. As a result, the quantity of political parties continues to increase but decreases in quality so that for the large number of political parties it is necessary to reduce the number or simplify for effectiveness, efficiency, prevent friction based on ethnicity, religion, race, and between groups (SARA) and maintain political stability and confusion voters in determining the choice of political parties during elections. The design of simplification of political parties in Indonesia can be carried out through the dissolution process by the Constitutional Court by expanding the parties that can apply for the dissolution of political parties (legal standing), the authority to impose sanctions by the government and a moratorium on granting permits for the establishment of new political parties. 


\section{BIBLIOGRAPHY}

\section{Books :}

Achmad Edi Subiyanto, 2019, Hakim Konstitusi: Kekuasaan Kehakiman dan Pengisian Jabatan, Rajawali Press, Depok;

Ahmad Siboy, 2013, Membongkar Politisasi Fungsi DPR, Intimedia, Malang;

Efriza and Syafuan Rozi, Parlemen Indoensia: geliat volksroad hingga DPD, ALFABETA, Bandung;

Fareed Zakaria, Bangkitnya Demokrasi Yang Tak Liberal, Article Group Amerika Dan Dunia: Memperdebatkan Bentuk Baru Politik Internasional, Yayasan Obor Indonesia, Jakarta;

Johny Ibrahim, 2008, Teori Dan Metodologi Penelitian Hukum Normatif, Bayu Media Publishing, Malang;

J.B.J.M. ten Berge, 2005, Bescherming Tegen Overheid, Zwolle: W.E.J. Tjenk Wilink.

Miriam Budiardjo, 2008, Dasar-dasar Ilmu Politik, Revision Edition, PT Gramedia Pustaka Utama, Jakarta;

Ridwan, 2009, Tiga Dimensi Hukum Administrasi dan Peradilan Administrasi, FH UII Press, Yogyakarta;

\section{Journals :}

Alya Yuliamaryam, Firdha Azkia, Prima Bhakti Persada, Wilda Nurfitriani, Hana Novia Wijaya, Abiyyu Ihsan Samudro, Penyederhanaan Partai Politik Berdasarkan Undang-Undang Pemilu 2017, Padjajaran Law Review, Volume 6 December 2018;

Aprista Ristyawati, Fifiana Wisnaeni, Hasyim Asy'ari, Penyederhanaan Partai Politik Dalam Sistem Kepartaian Di Indonesia Sejak Perubahan Undang-Undang 1945, Diponegoro Law Review, Volume 5 No. 2, March 2016;

Aras Firdaus, Money Politic Dalam Pemilihan Umum Oleh Badan Pengawasan Pemilihan Umum: Pengawasan Tindak Pidana Pemilu, Jurnal Justiqa, Vol.02 No. 01, February 2020;

Depri Liber Sonata, Metode Penelitian Hukum Normatif dan Empiris: Kharakteristik Khas dari Metode Meneliti Hukum, Jurnal Ilmu Hukum Fiat Justicia, Volume 8 No. 1, January-March 2014

Diastama Anggita Ramadhan, Menuju Penyederhanaan Partai Politik di Indonesia serta Dampaknya Terhadap Persatuan Bangsa, Adminitrative Law \& Governance Journal, Volume 2 Issue 4, November 2019;

Evi Noviati, Perkembangan Politik Hukum Pemilihan Umum Di Indonesia, Jurnal Galuh Yustisi, Volume 07 No. 1, March 2019; 
Imam Sukadi, Asas Contrarius Actus Sebagai Kontrol Pemerintah Terhadap Kebebasan Berserikat dan Berkumpul Di Indonesia, Jurnal Mimbar Keadilan, Volume 12 Nomor 2 August 2019 -January 2020;

Jane Theresia Silaban, dkk, Persepsi Mahasiswa Fisip Undip Terhadap Demokratisasi Di Indonesia, Jurnal IImu Pemerintahan Tahun 2013;

Mustaqiem, Moratorium Penerimaan Calon Pengawai Negeri Sipil dan Aspek Hukumnya, Jurnal Kebijakan dan Manajemen, PNS Vol. 5, No.2, November 2011;

Sutradara Gintings dan Ryaas Rasyid dalam Sunny Ummul Firdaus, Relevansi Parliamentary Threshold terhadap Pelaksanaan Pemilu yang Demokratis, Jurnal Konstitusi, Volume 8, Nomor 2, April 2010;

\section{Regulations}

Constitution of the Republic of Indonesia 1945

Act No. 3 of 1975 concerning Political Parties and Work Groups

Act No. 2 of 2011 concerning Political Parties

Act No. 7 of 2020 concerning the Third Amendment to Act No. 24 of 2003 concerning the Constitutional Court.

\section{Internet}

https://nasional.kompas.com/read/2018/02/20/13275281/partai-politik-yangbertarung-di-pemilu-dari-masa-ke-masa?page $=$ all

https://id.wikipedia.org/wiki/Partai_NasDem

https://id.wikipedia.org/wiki/Pembubaran_Hizbut_Tahrir_Indonesia

https://nasional.kompas.com/read/2014/05/09/2357075/Disahkan.KPU.Ini.Perol ehan.Suara.Pemilu.Legislatif.2014 